\title{
Insect pests associated with date palm cultivars at district Kech, Balochistan
}

\author{
Dawood Khan ${ }^{1}$, Shahab-u-din ${ }^{2 *}$, Abdul Ghani Lanjar ${ }^{1}$, Mukhtar Umer ${ }^{3}$, \\ Nazeer Ahmed ${ }^{2}$, Mohammad Aslam Mengal ${ }^{1}$ and Shafique Ahmed ${ }^{2}$ \\ 1. Department of Entomology, Sindh Agriculture University, Tandojam-Pakistan \\ 2. Agricultural Research Institute (BARDC), PARC, Turbat-Pakistan \\ 3. Date Research Center Turbat-Pakistan \\ *Corresponding author's email: shahabkashani64@gmail.com \\ Citation
}

Dawood Khan, Shahab-u-din, Abdul Ghani Lanjar, Mukhtar Umer, Nazeer Ahmed, Mohammad Aslam Mengal and Shafique Ahmed. Insect pests associated with date palm cultivars at district Kech, Balochistan. Pure and Applied Biology. Vol. 7, Issue 4, pp1177-1185. http://dx.doi.org/10.19045/bspab.2018.700137

\begin{tabular}{llll}
\hline \hline Received: $27 / 03 / 2018$ & Revised: 13/08/2018 & Accepted: $17 / 08 / 2018$ & Online First: 30/08/2018 \\
\hline
\end{tabular}

\section{Abstract}

To monitor the insect pest populations on date palm, different commercial cultivars such as, Begum Jangi, Muzwati, Shakri and Aseel were selected in district Kech of Balochistan during 2014. The pheromone traps were placed on date palm trees and weekly trap catches were counted for different insect pest species. The insect pests were identified as Lesser date moth (Batrachedra amydraula Meyrick), Red palm weevil (Rhynchophorus ferrugineus Olivier), Rhinoceros beetles (Oryctes spp.) and Scale insects (Parlatoria blanchardi) and (Phoenico coccusmarlatti Cockerell). This study was started from $07^{\text {th }}$ April 2014 to $06^{\text {th }}$ August, 2014 in order to monitor pest species on certain commercial cultivars. The results showed a significant $(\mathrm{P}<0.05)$ difference in date palm varieties for insect pest population. All the insect pests (red palm weevil, lesser date moth, beetles and scale insects) remained on trees. The red palm weevil catches were highest (79.82) on variety Shakri, while the lowest (39.35) trap catches were counted on variety Aseel. The Lesser date moth population was significantly higher (49.97) on variety Begum Jangi, while the low (24.83) seasonal trap catches counted on variety Aseel. The population of beetles was higher (199.64) on variety Shakri, while the seasonal lowest (101.46) population of beetles counted on variety Aseel. The population of scale insects was higher (104.19) on Shakri variety, while the seasonal lowest (52.24) population of scale insects were on variety Aseel. Variety Aseel indicated relative resistance to all the insect pests monitored, while variety Shakri was least accepting to insect pests with highest insect pest population.

Keywords: Date palm; Insect pests; Kech Balochistan; Peak population; Pheromone traps

Introduction

The date palm (Phoenix dactylifera L.) is known as one of the oldest fruit trees in the Arab region and it is extensively cultivated and famous for its eatable sweet fruit. Due to its long history of cultivation for fruits, its particular instinctive scattering is unknown but possibly originated wherever in the desert of northern Africa and perhaps also southwest Asia [1]. The major producers of dates in the world are situated in the Arabian Gulf and North Africa. The top 10 date palm producing countries include Egypt, Saudi Arabia, Iran, United Arab Emirates, Pakistan, Algeria, Sudan, Oman, Libya, and Tunisia. There are thousands of date palm cultivars, 
including those with soft, semi-dry, and dry fruits (depending on their water and type of sugar content at harvest when fully-ripe), are planted in these countries [2]. Date palm has a pronounced traditional significance in the Islamic world and with the increase of population in these countries; this tree not only offers the food but also a great number of other products which have been broadly used in the rural as well as urban areas of Pakistan. In Balochistan, district Kech (Turbat) and Panjgoor; in Sindh, Khairpur, Sukkur and Naushahro Ferozewhile in KPK, Dera Ismail Khan are major date palm producing areas of Pakistan. Regrettably its actual yield at the farm level is low as compared to its potential yield [3].

There are various issues faced by this key agricultural crop such as high and severe dry and hot conditions, insect pests and diseases etc. Among these, new insect pest species namely; Oriental wasp, Vinegar fly and Ramok, great date moth, lesser date moth, Ephestia mot, red palm weevil, dried fruits beetle, pineapple beetle, rhinoceros borer beetle, Oriental wasp and vinegar fly on date palm are most serious [4-6]. These pests not only damage the date palm tree but a cause of decline in the productivity of date fruit. These pests damage in different ways, due to which weight loss occurred every year. Thus, the objectives of present study were; to assess the population dynamics of insect pests on different date palm varieties in district Kech of Balochistan and; to examine the resistance in different date palm varieties against various insect pests in district Kech of Balochistan which will help to recommend the preventive and control measures against these pests.

\section{Materials and methods}

The study was conducted during the year 2014 on the "monitoring of date palm varieties cultivated in district Kech of Balochistan for population of various insect pests". The four date palm varieties assessed in an existing date palm area were 1) Begum Jangi; 2) Muzwati; 3) Shakri and 4) Aseel. The experiment was carried out in a randomized complete block design with four replicates. One date palm tree was considered as one replication and in this way four trees in each of four varieties were selected, making a total of 16 trees. The date palm trees were ensured for their good management and cultural practices. The populations of the insect pests were surveyed using pheromone traps. These pheromone traps were prepared locally, and the method of its preparation is very simple and affordable for an average grower. Plastic bottles containing trapping lure and hanging wire with surf water in the base were used. These were provided support with a stick and installed at the tree height so that the insect is trapped easily. One pheromone trap was sufficient for catching insect pests from one date palm tree. During trials the pheromone trap lures were replaced after one month for each variety. The experimental date palm trees were visited daily; however, the insect pest infestation was surveyed on weekly basis. The insect pests catch in each of the pheromone traps were separately protected in jars safely for identification and counting. After tenure of four weeks experiment, the pheromone traps were replaced with a set of new fabricated traps. During this four months experimental period, the pheromone traps were replaced for four times. During this time the weekly data for each insect pest was recorded while counting was done by placing the each trap on the paper sheet for each insect pest. The method of placing the pheromomes was adopted by [7, 8, 9]. However, for identification of insect pests, the trapped insects were carefully brought to the taxonomy lab at department of Entomology, Sindh Agriculture University, Tandojam, Pakistan for confirmation of their families up to species level. 


\section{Statistical analysis}

The data collected was subjected to statistical analysis using analysis of variance to know the significance of differences in the population of various insect pests and infestation at different intervals.The Least Significance Difference (LSD) Test was applied to compare date palm varieties for insect populations as well as during different dates of observations. The mean populations were derived from the primary data through statistical analysis, outlined by [10].

\section{Results and discussion}

The date palm in district Kech of Balochistan is cultivated on a large area and different varieties are cultivated. The data were collected form pheromone traps installed on date palm trees and weekly trap catches were identified and counted for different insect pest species. The identified species of insect pests trapped were Lesser date moth, Red palm weevil, Rhinicerus beetles and Scale insects.

\section{Red palm weevil (Rhynchophorous ferrugineus)}

Red palm weevil is the most devastating insect pest of date palm that attacks the tree foliage particularly trunk of palm. The results indicated that statistically the population of red palm weevil differed significantly for four date varieties $(\mathrm{F}=263.34, \mathrm{P}=0.0000$, $\mathrm{DF}=3)$ observation dates $(\mathrm{F}=55.56$, $\mathrm{P}=0.0000, \mathrm{DF}=17)$ as well as variety $\times$ observation date interaction $(\mathrm{F}=1.80$, $\mathrm{P}=0.0021, \mathrm{DF}=51, \mathrm{CV}=16.47 \%)$ (Table 1). The red palm weevil population on the basis of catches of pheromone traps was significantly higher on date palm variety Shakri (79.82) followed by Begum Jangi (64.02), Muzwati 46.82. The lowest population was observed on Aseel that was 39.35. This suggests that date palm varieties Aseel and Muzwati had a relative resistance to red palm weevil as compared to Shakri and Begum Jangi. The insectswere present on the tree throughout the observational period and the peak infestation level was observed on

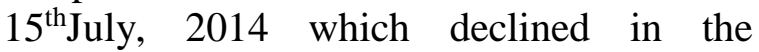
following week and the lowest trap catches were counted at the last observation on $06^{\text {th }}$ August, 2014. The date palm weevil gradually started its development from April onwards and persistently remained active on the tree infesting foliage and palm trunk. As the harvesting of fruits started, the insect population disturbed and it almost disappeared when trap catches counted on

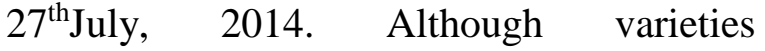
individually showed their resistance level to date palm weevil, but the trend of insect buildup was similar which was reflected from the peak population of date palm weevil and on all the varieties screened for insect resistance, the peak trap catches were counted on $8^{\text {th }}$ July, observation. These results are in agreement with the findings of [7] that weevil population peaked from April to June; however, they mentioned four population peaks whereas, in the present study population of weevil peaked up to the $15^{\text {th }}$ of July. This suggests that harvesting of fruits during this period disturbed the pest population. They suggested that there was a significant positive correlation between average temperature and adults population abundance of the weevil. Similarly, [8] also recorded that the weevil population occurred in four peaks a year in Wenchang, Hainan Province of China. However, the present study is in disagreement the above mentioned results as no positive correlation of population with the temperature was found rather the negative correlation of weevil population with the harvesting period i.e., in the month of July was observed.The weevil population continuously increased till the harvesting period [8].

\section{Lesser date moth (Batrachedr aamydraula Meyr)}

The lesser date mothis commercially most important insect pest of date palm which attacks the date fruits and causes huge losses. 
There are three generations of the insect per year. It appears in April and reportedly remains active on date palm tree even after the harvest of the fruits. The (Table 2) showed that the population of lesser date moth varied significantly among date palm varieties $(\mathrm{F}=139.37, \quad \mathrm{P}=0.0000, \quad \mathrm{DF}=3)$, observation dates $(\mathrm{F}=30.44, \quad \mathrm{P}=0.0000$, $\mathrm{DF}=17)$ as well as variety $\times$ observation date interaction $(\mathrm{F}=1.64, \mathrm{P}=0.0085, \mathrm{DF}=51, \mathrm{CV}=$ $22.42 \%$ ). The catches of pheromone traps counted on weekly basis showed that the lesser date moth population was significantly higher (49.97) on Begum Jangi followed Shakri, Muzwati and Aseel (40.76, 29.53 and 24.83, respectively). Considerable resistance to lesser date moth was showed by Aseel and Muzwati varieties of date palm as compared to beghum Jangi and Shakri.However, variety Aseel exhibited and maintained its resistance level with least population of red palm weevil as well as lesser date moth. The lesser date moth was shown on date palm tree throughout the observational period and its peak infestation level was observed on $23^{\text {rd }}$ July, 2014 and later declined sharply in the following weeks reaching the lowest level on $06^{\text {th }}$ August, 2014. These results are in disagreement with the finding of [9] who reported that the peak population of the pest was attainedin the month of June while the lesser date moth showed their populations build up with a regular span and as the date palm fruits developed towards maturity, the insect population increased simultaneously. It may be due to the difference in the temperature of both locations. The temperature of Kech during May and June was quite high and as soon the temperature decreases its population started to develop. However, as the harvesting of fruits began, the insect population diminished as observed from the trap catches on $06^{\text {th }}$ August. On the contrary, in UAE, the highest trap catches were observed in the month of April [2].

\section{Rhinoceros beetles (Oryctes spp)}

Oryctes is the most economically important genus of rhinoceros beetles in the subfamily Dynastinae (family: Scarabaeidae). Beetlesare generally found on date palm trees in greater number when comparing with the other insect pests infesting date palm fruit and foliage. The population monitored on the basis of insect catches from pheromone traps and identified as beetles on weekly basis. Different beetle species were found during the present study on date palm trees from April till the fruit harvesting. In data the (Table 3) describes that the population of Oryctes spp. varied significantly for date palm varieties ( $\mathrm{F}=300.62, \mathrm{P}=0.0000, \mathrm{DF}=3)$, observation dates $(\mathrm{F}=69.01, \mathrm{P}=0.0000, \mathrm{DF}=17)$, and variety $\times$ observation date interaction $(\mathrm{F}=2.07, \mathrm{P}=0.0002, \mathrm{DF}=51, \mathrm{CV}=14.79 \%)$. Results indicated that the beetles populationwas significantly higher (199.64) on date palm variety Shakri followed by Begum Jangi, Muzwati and Aseel with 167.83, 120.97 and 101.46 numbers, respectively. The peak population (276.00) of beetles on Shakri was recorded in the last week of June on Begum Jangi (232.00) and Aseel (142.75) on $7^{\text {th }}$ July. Whereas, on Muzwati the peak population of beetles was observed on $15^{\text {th }}$ July. It was noted that date palm variety Aseel exhibitedthe significant resistance to beetles and minimum infestation was observed on this variety throughout the fruiting season while Shakri and Begum Jangi were found to be less resistant to beetles. Moreover, it was observed that beetles build up high population on Shakri variety earlier than other varieties. The seasonal up and down in the population of different beetle species demonstrated that these insect species are found to be present in large number when the study was beginning and when the pheromone traps were in the process of installation. Initially, weekly count of trap catches was 113.90 which gradually 
developed with the development of date palm fruit and reached at its highest infestation level (202.50) on $7^{\text {th }}$ July. Later, the beetle population started decreasing and reached to its minimum when the population was monitored on $06^{\text {th }}$ August. These data insure the same observation obtained by [7] who found that, the population of Rhinoceros occurred in four peaks a year. The same results with finding of [11], who observed that there four peaks of emergence during the march, May, July and October.

Table 1. Seasonal weekly population of red palm weevil monitored by pheromone traps and evaluation of varietal resistance to insect pests from $7^{\text {th }}$ April 2014 to $06^{\text {th }}$ August 2014

\begin{tabular}{|c|c|c|c|c|c|}
\hline \multirow{2}{*}{$\begin{array}{c}\text { Observation } \\
\text { date }\end{array}$} & \multicolumn{4}{|c|}{ Date palm varieties } & \multirow{2}{*}{ Average } \\
\hline & Begum Jangi & Muzwati & Shakri & Aseel & \\
\hline 07.04 .2014 & 49.25 & 36.00 & 60.25 & 30.25 & $44.00 \mathrm{f}$ \\
\hline 14.04 .2014 & 53.25 & 38.75 & 65.25 & 32.75 & $47.50 \mathrm{f}$ \\
\hline 21.04 .2014 & 55.75 & 40.75 & 68.25 & 34.50 & $49.75 \mathrm{e}$ \\
\hline 28.04 .2014 & 58.75 & 43.00 & 72.00 & 36.00 & $52.43 \mathrm{e}$ \\
\hline 05.05 .2014 & 62.00 & 45.25 & 76.50 & 38.00 & $55.43 \mathrm{e}$ \\
\hline 12.05 .2014 & 65.75 & 48.50 & 81.00 & 40.75 & $59.00 \mathrm{~d}$ \\
\hline 19.05 .2014 & 67.50 & 49.25 & 83.00 & 41.25 & $60.25 \mathrm{~d}$ \\
\hline 26.05 .2014 & 68.75 & 50.25 & 84.50 & 42.25 & $61.43 \mathrm{~d}$ \\
\hline 02.06 .2014 & 70.25 & 51.25 & 86.50 & 43.25 & $62.81 \mathrm{~d}$ \\
\hline 09.06 .2014 & 72.50 & 53.00 & 89.00 & 44.50 & $64.75 \mathrm{~d}$ \\
\hline 16.06 .2014 & 79.75 & 58.50 & 98.00 & 49.00 & $71.31 \mathrm{c}$ \\
\hline 23.06 .2014 & 81.00 & 59.50 & 99.75 & 49.75 & $72.50 \mathrm{~b}$ \\
\hline 30.06 .2014 & 84.25 & 61.50 & 103.50 & 52.00 & $75.31 \mathrm{~b}$ \\
\hline 07.07 .2014 & 87.25 & 63.75 & 107.00 & 53.75 & $77.93 \mathrm{~b}$ \\
\hline 15.07 .2014 & 89.75 & 65.50 & 130.50 & 55.25 & $85.25 \mathrm{a}$ \\
\hline 23.07 .2014 & 60.50 & 44.25 & 74.50 & 37.00 & $54.06 \mathrm{e}$ \\
\hline 30.07 .2014 & 33.50 & 24.50 & 41.00 & 20.50 & $29.87 \mathrm{~g}$ \\
\hline 06.08 .2014 & 12.75 & 9.25 & 16.00 & 7.75 & $11.44 \mathrm{~h}$ \\
\hline Average & $64.02 \mathrm{~b}$ & $46.82 \mathrm{c}$ & $79.82 \mathrm{a}$ & $39.35 \mathrm{~d}$ & - \\
\hline & \multicolumn{2}{|c|}{ Varieties (V) } & \multicolumn{2}{|c|}{ Observation dates (D) } & $\mathbf{V} * \mathbf{D}$ \\
\hline \multicolumn{2}{|l|}{ S.E. } & .5786 & \multicolumn{2}{|c|}{3.3487} & 6.6975 \\
\hline \multicolumn{2}{|c|}{ LSD 0.05} & 1117 & \multicolumn{2}{|c|}{6.6009} & 13.202 \\
\hline \multicolumn{2}{|c|}{ LSD 0.01} & 1030 & \multicolumn{2}{|c|}{8.7037} & 17.407 \\
\hline
\end{tabular}

Table 2. Seasonal weekly population of lesser date moth monitored by pheromone traps and evaluation of varietal resistance to insect pests from $7^{\text {th }}$ April 2014 to $06^{\text {th }}$ August 2014

\begin{tabular}{|c|c|c|c|c|c|}
\hline $\begin{array}{c}\text { Observation } \\
\text { date }\end{array}$ & \multicolumn{4}{|c|}{ Date palm varieties } & \multirow{2}{*}{ Average } \\
\cline { 2 - 5 } & Begum Jangi & Muzwati & Shakri & Aseel & \\
\hline 07.04 .2014 & 35.50 & 22.75 & 26.25 & 19.25 & $25.94 \mathrm{e}$ \\
\hline 14.04 .2014 & 39.00 & 24.50 & 33.50 & 20.50 & $29.37 \mathrm{~d}$ \\
\hline 21.04 .2014 & 43.00 & 25.50 & 35.00 & 21.75 & $31.31 \mathrm{~d}$ \\
\hline 28.04 .2014 & 45.50 & 26.75 & 37.00 & 22.75 & $33.00 \mathrm{~d}$ \\
\hline 05.05 .2014 & 48.00 & 28.75 & 34.00 & 24.00 & $33.68 \mathrm{~d}$ \\
\hline 12.05 .2014 & 51.00 & 30.50 & 41.50 & 25.50 & $37.12 \mathrm{c}$ \\
\hline 19.05 .2014 & 52.25 & 31.25 & 37.50 & 26.25 & $36.81 \mathrm{c}$ \\
\hline 26.05 .2014 & 53.25 & 31.75 & 43.50 & 26.75 & $38.81 \mathrm{c}$ \\
\hline 02.06 .2014 & 54.50 & 32.50 & 44.50 & 27.25 & $39.68 \mathrm{c}$ \\
\hline
\end{tabular}




\begin{tabular}{|c|c|c|c|c|c|}
\hline 09.06 .2014 & 56.00 & 33.25 & 45.50 & 28.00 & $40.68 \mathrm{c}$ \\
\hline 16.06 .2014 & 61.50 & 37.00 & 50.25 & 31.25 & $45.00 \mathrm{~b}$ \\
\hline 23.06 .2014 & 62.75 & 37.50 & 51.25 & 31.25 & $45.68 \mathrm{~b}$ \\
\hline 30.06 .2014 & 65.25 & 38.75 & 50.50 & 32.50 & $46.75 \mathrm{~b}$ \\
\hline 07.07 .2014 & 67.25 & 40.25 & 54.75 & 33.75 & $49.00 \mathrm{a}$ \\
\hline 15.07 .2014 & 46.50 & 27.75 & 63.25 & 23.50 & $40.25 \mathrm{c}$ \\
\hline 23.07 .2014 & 82.25 & 41.50 & 56.50 & 34.75 & $53.75 \mathrm{a}$ \\
\hline 30.07 .2014 & 26.00 & 15.25 & 21.00 & 13.00 & $18.81 \mathrm{f}$ \\
\hline 06.08 .2014 & 10.00 & 6.00 & 8.00 & 5.00 & $7.25 \mathrm{~g}$ \\
\hline Average & $49.97 \mathrm{a}$ & $29.53 \mathrm{c}$ & $40.76 \mathrm{~b}$ & $24.83 \mathrm{~d}$ & - \\
\hline \multicolumn{7}{|c|}{ Varieties(V) } & \multicolumn{3}{|c|}{ Observation dates (D) } & V*D \\
\hline S.E. & 1.3557 & \multicolumn{2}{|c|}{5.6759} & 5.7517 \\
\hline LSD 0.05 & 2.6723 & \multicolumn{2}{c|}{7.4746} & 11.337 \\
\hline LSD 0.01 & 3.5236 & \multicolumn{5}{c|}{} \\
\hline
\end{tabular}

Table 3. Seasonal weekly population of beetles monitored by pheromone traps and evaluation of varietal resistance to insect pests from $7^{\text {th }}$ April 2014 to $06^{\text {th }}$ August 2014

\begin{tabular}{|c|c|c|c|c|c|}
\hline \multirow{2}{*}{$\begin{array}{c}\text { Observation } \\
\text { date }\end{array}$} & \multicolumn{4}{|c|}{ Date palm varieties } & \multirow{2}{*}{ Average } \\
\hline & Begum Jangi & Muzwati & Shakri & Aseel & \\
\hline 07.04 .2014 & 127.50 & 93.25 & 156.50 & 78.50 & $113.94 \mathrm{e}$ \\
\hline 14.04 .2014 & 138.00 & 100.75 & 169.50 & 84.75 & $123.25 \mathrm{e}$ \\
\hline 21.04 .2014 & 144.00 & 105.25 & 177.25 & 88.50 & $128.75 \mathrm{~d}$ \\
\hline 28.04 .2014 & 151.75 & 111.00 & 186.50 & 93.25 & $135.63 \mathrm{~d}$ \\
\hline 05.05 .2014 & 160.50 & 117.50 & 197.50 & 98.50 & $143.50 \mathrm{~d}$ \\
\hline 12.05 .2014 & 171.00 & 125.00 & 210.00 & 105.00 & $152.75 \mathrm{c}$ \\
\hline 19.05 .2014 & 175.00 & 127.75 & 214.75 & 107.50 & $156.25 \mathrm{c}$ \\
\hline 26.05 .2014 & 178.75 & 130.50 & 219.50 & 110.00 & $159.69 \mathrm{c}$ \\
\hline 02.06 .2014 & 182.50 & 133.50 & 224.00 & 112.25 & $163.06 \mathrm{c}$ \\
\hline 09.06 .2014 & 187.25 & 137.00 & 230.00 & 115.25 & $167.37 \mathrm{c}$ \\
\hline 16.06 .2014 & 206.75 & 151.00 & 254.00 & 126.75 & $184.63 \mathrm{~b}$ \\
\hline 23.06 .2014 & 210.50 & 153.75 & 258.50 & 129.50 & $188.06 \mathrm{~b}$ \\
\hline 30.06 .2014 & 218.00 & 159.25 & 276.00 & 134.00 & $196.81 \mathrm{a}$ \\
\hline 07.07 .2014 & 232.00 & 164.75 & 268.50 & 142.75 & $202.50 \mathrm{a}$ \\
\hline 15.07 .2014 & 225.75 & 168.75 & 245.00 & 138.75 & $194.56 \mathrm{a}$ \\
\hline 23.07 .2014 & 156.75 & 114.50 & 192.50 & 96.50 & $140.06 \mathrm{~d}$ \\
\hline 30.07 .2014 & 132.00 & 63.50 & 106.50 & 53.00 & $88.75 \mathrm{e}$ \\
\hline 06.08 .2014 & 23.00 & 19.50 & 6.00 & 11.50 & $15.00 \mathrm{f}$ \\
\hline Average & $167.83 \mathrm{~b}$ & $120.97 \mathrm{c}$ & $199.64 \mathrm{a}$ & $101.46 \mathrm{~d}$ & -- \\
\hline & Varieties & & vation dat & & D \\
\hline S.E. & 3.634 & & 7.7092 & & 418 \\
\hline LSD 0.05 & 7.163 & & 15.196 & & 392 \\
\hline LSD 0.01 & 9.445 & & 20.037 & & 074 \\
\hline
\end{tabular}

Scale insects (Parlatoria blanchardi and Phoenico coccusmarlattu)

Scale insects are the pests that are harmful for the date palm tree for its foliage, stem as well as the fruits. It is the two major insect species were found infesting date palm. [4] announced the economic importance for fourteen insect pests. These pests namely are green scale Asterolecanium phoenicis Ramachanda Rao, gray date scale Parlatoria 
blanchardi (Targioni Tozzetti) and red scale Phoenico coccusmarlatti Cockerell. The weekly trap catches record is evidence of their presence at first observation on 7 th April, 2014. The data (Table 4) exhibited that statistically the population of scale insects differed significantly for date palm varieties $(\mathrm{F}=362.97, \mathrm{P}=0.0000, \mathrm{DF}=3)$, observation dates $(\mathrm{F}=86.38, \mathrm{P}=0.0000, \mathrm{DF}=17)$ as well as variety $\times$ observation date interaction $(\mathrm{F}=2.24, \mathrm{P}=0.0000, \mathrm{DF}=51, \mathrm{CV}=13.71 \%)$. The population of scale insects calculated from the pheromone trap catches on weekly basis resulted that the population of scales on different date palm varieties was significantly higher (104.19) on Shakri variety, while the seasonal average trap catches calculated on varieties Begum Jangi, Muzwati and Aseel were 84.58, 61.96 and 52.24, respectively. The high population of Shakri (148.75) and Begum Jangi (119.00) was recorded on 15th July observation, and high population of Aseel (73.25) was monitored on 30th June observation. The varietal behavior towards the infestation of scale insects indicated that Shakri was relatively susceptible to scale insects showing peak insect population throughout the date palm fruiting season, while Aseel variety proved to be resistant to the insect infestation with lowest population of insects throughout the date palm fruiting season among all the varieties evaluated. The trend of infestation of scale insects on date palm throughout the fruiting season remained same in all varieties regardless the fluctuation in the infestation. The seasonal variation in the population of different scale insects indicated that these insects stayed present in the date palm garden round the year and at the time of commencement of this study and installation of pheromone traps on trees these insect species were abundantly present. Initially the weekly count of trap catches was 58.50 which resulted a fast development during following weeks and reached at the high infestation level of 105.06 on $15^{\text {th }}$ July. However, later the scale insect's population started decreasing and almost vanished when population was monitored on $06^{\text {th }}$ August [12] observed the lesser date moth (Batrachedra amydraula Myer), the bigger moth (Arenipses Sabella Hmpsn), termite (Microcerote rmesdiversus Silve.), the horned beetle (Oryctes elegans Prell), the long anntenal beetles (Pseudophilus testaceus Gab), white scale (Parlatoria blanchardi Targ), Khamedje disease (Mauginellascattae Cav) and leaf spot on date palm [13]. Moreover, [6] reported that high level of Ommatissuslybicus Debergevin was recorded in date palm gardens.

Table 4. Seasonal weekly population of scale insects monitored by pheromone traps and evaluation of varietal resistance to insect pests from $7^{\text {th }}$ April 2014 to $06^{\text {th }}$ August 2014

\begin{tabular}{|c|c|c|c|c|c|}
\hline $\begin{array}{c}\text { Observation } \\
\text { date }\end{array}$ & \multicolumn{4}{|c|}{ Date palm varieties } & \multirow{2}{*}{ Average } \\
\cline { 2 - 5 } & Begum Jangi & Muzwati & Shakri & Aseel & \\
\hline 07.04 .2014 & 65.50 & 48.00 & 80.25 & 40.25 & $58.50 \mathrm{f}$ \\
\hline 14.04 .2014 & 70.75 & 51.75 & 86.75 & 43.50 & $63.19 \mathrm{e}$ \\
\hline 21.04 .2014 & 74.25 & 54.25 & 91.00 & 45.50 & $66.25 \mathrm{e}$ \\
\hline 28.04 .2014 & 78.00 & 56.75 & 96.00 & 48.00 & $69.69 \mathrm{~d}$ \\
\hline 05.05 .2014 & 82.25 & 60.50 & 101.50 & 50.75 & $73.75 \mathrm{~d}$ \\
\hline 12.05 .2014 & 87.75 & 64.00 & 108.00 & 54.00 & $78.44 \mathrm{c}$ \\
\hline 19.05 .2014 & 89.75 & 65.50 & 110.00 & 55.25 & $80.12 \mathrm{c}$ \\
\hline 26.05 .2014 & 91.75 & 67.00 & 112.75 & 56.50 & $82.00 \mathrm{c}$ \\
\hline 02.06 .2014 & 93.75 & 68.50 & 115.25 & 57.50 & $83.75 \mathrm{c}$ \\
\hline 09.06 .2014 & 96.25 & 70.25 & 118.00 & 59.25 & $85.94 \mathrm{~b}$ \\
\hline 16.06 .2014 & 106.25 & 77.50 & 130.25 & 65.25 & $94.81 \mathrm{~b}$ \\
\hline
\end{tabular}




\begin{tabular}{|c|c|c|c|c|c|}
\hline 23.06 .2014 & 108.25 & 79.00 & 133.00 & 66.25 & $96.63 \mathrm{~b}$ \\
\hline 30.06 .2014 & 112.00 & 82.00 & 137.50 & 73.25 & $101.12 \mathrm{a}$ \\
\hline 07.07 .2014 & 116.00 & 88.50 & 142.50 & 71.25 & $104.56 \mathrm{a}$ \\
\hline 15.07 .2014 & 119.00 & 83.25 & 148.75 & 69.00 & $105.06 \mathrm{a}$ \\
\hline 23.07 .2014 & 80.50 & 58.75 & 99.00 & 49.50 & $71.94 \mathrm{~d}$ \\
\hline 30.07 .2014 & 44.75 & 32.50 & 54.75 & 27.50 & $39.87 \mathrm{~g}$ \\
\hline 06.08 .2014 & 5.75 & 7.25 & 10.25 & 7.75 & $7.75 \mathrm{~h}$ \\
\hline Average & $84.58 \mathrm{~b}$ & $61.96 \mathrm{c}$ & $104.19 \mathrm{a}$ & $52.24 \mathrm{~d}$ & -- \\
\hline & \multicolumn{2}{|c|}{\begin{tabular}{|l|} 
Varieties $(\mathbf{V})$ \\
\end{tabular}} & \multicolumn{2}{|c|}{ Observation dates (D) } & $\mathbf{V} * \mathbf{D}$ \\
\hline S.E. & \multicolumn{2}{|c|}{1.7304} & \multicolumn{2}{|c|}{3.6703} & 7.3414 \\
\hline LSD 0.05 & \multicolumn{2}{|c|}{3.4109} & 7.2355 & \multicolumn{2}{|c|}{14.471} \\
\hline LSD 0.01 & \multicolumn{2}{|c|}{4.4974} & 9.5405 & \multicolumn{2}{|c|}{19.081} \\
\hline
\end{tabular}

\section{Conclusions}

A highly significant $(\mathrm{P}<0.05)$ variation in date palm varieties was recorded for insect pest population. The trap catches were recognized as red palm weevil, lesser date moth, beetles and scale insects. All these insect pests remained on trees throughout the fruiting season of date palm infesting foliage and fruits. However, as the harvesting of fruits began, the insect population disturbed and it almost vanished. The high populations of date palm weevil and beetle species on the basis of trap catches were counted on $7^{\text {th }}$ July. The lesser date moth in touched at its peak infestation level on $23^{\text {rd }}$ July and later decreased sharply. The peak population of scale insects recorded from trap catches was on $15^{\text {th }}$ July. Variety Aseel expressed relative resistance to all the insect pests monitored in this study, followed by Muzwati in resistance; while variety Shakri was least tolerant to insect pests with highest insect pest population throughout the season.

\section{Authors' contributions}

Conceived and designed the experiments; D Khan \& AG Lanjar, Performed the experiment; D Khan \& M Umer, Analyzed the data; S Ahmed, Contributed reagents/ material/ analysis tools; MA Mengal \& N Ahmed, Wrote the paper: S Din \& D Khan.

\section{References}

1. El-Shibli S \& Korelainen H (2009). Biodiversity of date palm (Phoenix dactylifera L.) in Sudan: Chemical, morphological and DNA polymorphism of selected cultivars. Plant Genetic Resour (7): 194-203.

2. Kader AA \& Hussein AM (2009). Harvesting and Post-harvest handling of dates, International Center for Agricultural Research in the Dry Areas (ICARDA).

3. PARC (2009). Date palm. Pakistan Agricultural Research Council (PARC), Islamabad.

http://www.parc.gov.pk/1 subdivisions/n arccsi/horticul/Datepalm.html.

4. Antary TM, Al-Khawaldeh AMM \& Ateyyat MA (2015). Economic importance of date palm Phoenix dactylifera L. (Liliopsida: Arecales: Arecaceae) pests in Jordan Valley. Brazilian J Biol Sci 2(3): 121-134.

5. Baloch HB, Rustamani, Khuro MA, Talpur RD, Hussain MA (1994). Incidence and abundance of date palm weevil in different cultivars of date palm. Proceedings of Pakistan Congress of Zoology. Twelfth Pakistan Congress of Zoology held under auspices of the Zoological Society of Pakistan Government College, Lahore, (12): 445447.

6. Khalaf MZ \& Khudhair MW (2015). Spatial distribution of Dubas bug, Ommatissuslybicus (Homoptera: Tropiduchidae) in date palm frond rows. Integrated Pest Control Res pp 1-9. 
7. EL-Lakwah FAM, EL-Banna AA, ELHosary RA \& EL-Shafei WKM (2011). Population dynamics of the red palm weevil, Rhynchophorus ferrugineus (OLIV.) on date palm plantations in 6th October governorate. Egypt J Agri Res 89(3): 1105-1118.

8. Quan ZW, Long MZ, Yang WD, Zhuo CX, Wang YZ, Zhao $\mathrm{H}$ \& Wen HC (2004). Trapping of Red Palm Weevil with Several Attractants and Monitoring of Its Population in the Field. Chinese $J$ Tropical Crops 4(2): 42-46.

9. Hashim SM, Abdullah FF \& Tawfik HM (2013). Monitoring studies of the red palm weevil Rhynochophorus ferrugineus using pheromone traps in palm tree orchards. Palm pest Mediterranean conference NICE 16-18 January, 2013.

10. Gomes KA \& Gomez AA (1984). Statistical procedures for Agricultural research. 2 ed. John wiley and sons; New York (USA).

11. Abdallah FF \& Khatri SAA (2003). Seasonal fluctuation of Rhychoporus ferrugineous (Oliv) Coleoptera curculionidea in Sultanate of Oman. International Conference on Date Palm (2003) Kingdom of Saudi Arabia King Saud University.

12. Latifian M, Rahnama AA \& Sharifnezhad H (2012). Effects of planting pattern on major date palm pests and diseases injury severity. Int J Agri Crop Sci 4(19): 1443-145.

13. Abbas M, Hafeez F, Ali A, Farooq M, Latif M, Saleem M \& Ghaffar A (2014). Date palm white scale (Parlatoriablanchardi $\mathrm{T}$ ): a new threat to date industry in Pakistan. $J$ of Ento and Zool Studies 2(6): 49-52. 